\title{
INTEGRATION BETWEEN CULVERT AND EMBANKMENT FOR PROTECTION AGAINST FLOODS*
}

\author{
Maha R. F. El-zawalatry** \\ Water Engineering Department., Zagazig University, Egypt
}

\begin{abstract}
Culvert is considered one of the main available solutions to avoid failure due to flooding. It's constructed at intersection of a wadi with highway to remove excess water from upstream of highway to downstream to avoid failure of road above culvert. All over the world, we have problems due to the different construction failure across the path of flood. In this paper, we modified the construction of highway above culvert to work as a broad crested weir and integrated with culvert to pass the discharge increases over the culvert. Extensive experimental works were conducted to pipe culvert. Different parameters are studied such as highway height above culvert $(\mathrm{h}=3.5 \mathrm{~cm}, 7.50 \mathrm{~cm}$, and $10.5 \mathrm{~cm})$, upstream and downstream side slopes of highway which are $0 \mathrm{H}: 1 \mathrm{~V}, 1 \mathrm{H}: 1 \mathrm{~V}, 1.5 \mathrm{H}: 1 \mathrm{~V}, 2 \mathrm{H}: 1 \mathrm{~V}$, and $2.5 \mathrm{H}: 1 \mathrm{~V}$. The length of highway above culvert was also studied at different ratios: $30 \%, 44 \%, 58 \%, 72 \%$, and $100 \%$. Finally, all parameters were measured at different bed channel slopes: 0.0, 0.002, 0.004 and 0.006. This study aims to obtain the optimum design of the highway to work as a broad crested weir above culvert with submerged flow to remove the excessive discharge from upstream to downstream of highway. Different figures, and developed empirical equations-to help engineering in design- are also presented.
\end{abstract}

KEY WORDS: Culvert, Embankment, Weir, Flood, Highway, Broad crested weir

\section{INTEGRATION ENTRE PONCEAU ET LE REMBLAI POUR LA PROTECTION CONTRE LES INONDATIONS}

\section{RÉSUMÉ}

Ponceau est considéré comme l'un des principales solutions disponibles pour éviter l'échec à cause des inondations. C'est construit à l'intersection d'un oued avec des autoroutes pour enlever l'excès d'eau de l'amont à l'aval de l'autoroute pour éviter l'échec de la route au-dessus du ponceau. Partout dans le monde, nous avons des problèmes à cause de l'échec de la construction différents à travers le chemin de la crue. Dans ce papier, nous avons modifié la construction de l'autoroute au-dessus du ponceau pour travailler comme un large déversoir à crête et intégré avec ponceau à passer la décharge augmente au fil du ponceau. D'importants travaux expérimentaux ont été menés pour ponceau. Différents paramètres sont étudiés tels que la hauteur au-dessus de l'autoroute ponceau $(\mathrm{h}=3.5 \mathrm{~cm}, 7.50 \mathrm{~cm}$, et $10.5 \mathrm{~cm})$, les pentes en amont et en aval de la route qui sont $0 \mathrm{H}: 1 \mathrm{~V}, 1 \mathrm{H}: 1 \mathrm{~V}, 1,5 \mathrm{H}: 1 \mathrm{~V}, 2 \mathrm{H}: 1 \mathrm{~V}$, et $2.5 \mathrm{~h}: 1 \mathrm{~V}$. La longueur de la route au-dessus du ponceau a également été étudiée dans des proportions différentes: $30 \%, 44 \%, 58 \%, 72 \%$ et $100 \%$. Enfin, tous les paramètres ont été mesurés à différentes pentes de canal lit: 0,0,0,002, 0,004 et 0,006. Cette étude vise à obtenir la conception optimale de l'autoroute à travailler comme un large déversoir à crête au-dessus du ponceau avec un débit submergée pour supprimer la décharge excessive de l'amont à l'aval de l'autoroute. Chiffres différents, et développé les équations empiriques à l'aide d'ingénierie en conception-sont également présentées.

Mots-Clés: le ponceau, Berge, Weir, Flood, autoroute, large crête du déversoir

* Received: 27/4/2011, accepted: 28/5/2011 (Original Paper)

** Contact author (maha205066@yahoo.com) 


\section{INTRODUCTION}

This research combined between culvert and embankment to pass the maximum discharge of wadi or waterway. It also suggested modification of embankment to work as weir by changing the geometry of slope in upstream and downstream. Referring to: The overtopping flow above embankment discussed by Scholl, B. N., et al. (2000, 2009), U.S. Department of transportation (2005), and Taxes Department of Transportation (2004) in which they discussed the equations of overtopping and the design chart for the different parameters. Additionally, the design of culvert equations and the energy dissipaters discussed by U.S. Department of Transportation in (2006), Cordes, K. E. and Hotchkiss, R.H (1993). Thus, the optimal culverts sizes were developed to estimate the design floods by taking the critical storm duration into consideration to design discharge by Kang, M.S. et al.(2009), Najafi, M. and Bhattachar, V.(2010), Masada, T. et al(2007). They discussed risk assessment method developed by the ODOT approach. Charbeneau, R. J.et al. (2006) presented a versatile twoparameter model describing the hydraulic performance of highway culverts operating under inlet control for both un-submerged and submerged conditions. Dasika, B. (1995) presented new approach to design culverts under inlet control. He recommended that the culvert is designed to flow under outletcontrol conditions. Sargison, J. E. and Percy, A.(2009) investigated the flow of water over a sloped broad crested weir in upstream and downstream. He developed empirical equation to determine the discharge coefficient that was written as $\mathrm{C}_{\mathrm{dw}}=0.43+0.06 \sin [\pi(\varepsilon-0.55)]-$

$0.0396 \theta+0.0039$, in which $\varepsilon=\left(\mathrm{H}_{\mathrm{r}} /\left(\mathrm{H}_{\mathrm{r}}+\mathrm{L}\right)\right.$, for $0<\varepsilon<1$ and $\theta$ is the influence upstream face angle. Fritz $H$. M. and Hager W. H.(1998) discussed the design of overtopping embankment for upstream and downstream slopes $2 \mathrm{H}$ : $1 \mathrm{~V}$. They determined the discharge coefficient $\mathrm{C}_{\mathrm{dw}}=0.43+0.06 \sin [\pi(\varepsilon-0.55)]$ and drew the streamlines profile above weirs for free and submerged flow. The hydraulic characteristics for rapidly varying flow over oblique weirs were studied by Wlos B., et al.(2006). Saker. M. A. and Rhodes D. G.(2004) measured the flow surface profile above broad crested weir and compared it with results of numerical models. The hydraulic performance curves for highway culverts in case of inlet control for both submerged and un-submerged were presented by Charbeneay R. J., et al.(2006). Masada T. et al. (2007) presented a risk assessment method to compute the overall structural health rating for any inspected culvert. Measelhe, E. A., et al.(2007), Hager W. H.and Del Giudice G.(1998) discussed the generalized design culvert and the flow measurements through culverts.

\section{MATHEMATICAL APPROACH}

Flow through culvert and weirs is functioned in different parameters. These parameters are upstream head above the crest in upstream $\left(\mathrm{H}_{\mathrm{r}}\right)$, downstream $\left(\mathrm{h}_{\mathrm{r}}\right)$, horizontal length of highway(B), height of highway above culvert(p), upstream and downstream side slope $\left(\mathrm{S}_{\mathrm{s}}\right)$, channel bed slope $\left(\mathrm{S}_{\mathrm{e}}\right)$, Length of highway above culvert (L), discharge coefficient of culvert $\left(\mathrm{C}_{\mathrm{dc}}\right)$, discharge coefficient of highway above culvert $\left(\mathrm{C}_{\mathrm{dw}}\right)$, culvert length $\left(\mathrm{L}_{\mathrm{c}}\right)$, upstream water $\operatorname{depth}\left(\mathrm{y}_{\mathrm{o}}\right)$, tail water $\operatorname{depth}\left(\mathrm{y}_{\mathrm{t}}\right)$, and culvert discharge $\left(\mathrm{Q}_{\mathrm{c}}\right)$, discharge above highway $\left(\mathrm{Q}_{\mathrm{w}}\right)$, total discharge $\left(\mathrm{Q}_{\mathrm{T}}\right)$. These parameters are combined with flow characteristics, fluid characteristics and boundary characteristics to deduce the dimensional function used for the analysis of the phenomena. Figure 1 shows a diagram to the tested model. 


\subsection{Culvert Discharge}

By applying the principles of continuity and energy equations, the discharge equation for the culvert and overtopping highway above culvert can be written as follows (Richard F.(1985) and Ven Te Chow (1959)): For sloped channel

$$
Q_{c}=c_{d c} A_{o} \sqrt{\frac{2 g\left(y_{0}-y_{t}\right)+S_{e} L_{c}}{1+\left(k \cdot c_{d c}^{2} \cdot n^{2} L_{c} / R^{4 / 3}\right)}}
$$

For horizontal channel

$$
Q_{c}=c_{d c} A_{o} \sqrt{\frac{2 g\left(y_{0}-y_{t}\right)}{1+\left(k \cdot c_{d c}^{2} \cdot n^{2} L_{c} / R^{4 / 3}\right)}}
$$

In which:

$\mathrm{A}_{\mathrm{o}}=$ culvert cross-section, $\mathrm{k}=$ coefficient equals 29 for English system and 19.65 for international system, and $\mathrm{R}=$ hydraulic radius., $\mathrm{L}_{\mathrm{c}}=$ length of culvert, $\mathrm{y}_{\mathrm{o}}=$ upstream water depth, $\mathrm{y}_{\mathrm{t}}=$ tail water depth, $\mathrm{c}_{\mathrm{dc}}=$ culvert discharge coefficient, $\mathrm{g}=$ gravitational acceleration, $\quad \mathrm{n}=$ roughness $\quad$ Manning coefficient

Equations (1) and (2) are valid for submerged outlet,

$$
\left(\left(y_{o}-p\right) / d\right) \succ 1 \text {, and } \quad y_{t} / d \succ 1 \text {. }
$$

\subsection{Highway Overtopping Discharge}

The discharge of highway overtopping can be computed by the following equation:

$Q_{w}=K_{1} \cdot C_{d w} \cdot$ B. $H_{r}^{1.5}$

In which

$\mathrm{Q}_{\mathrm{w}}=$ discharge overtopping highway, $\mathrm{C}_{\mathrm{dw}}$ =discharge coefficient equal 1.66 for SI and 3 for English system, B=horizontal length of overflow perpendicular of the flow direction, $\mathrm{k}_{1}=$ over-embankment factor, and $\mathrm{H}_{\mathrm{r}}=$ upstream head above crest of highway. The total discharge passes from the channel $\mathrm{Q}_{\mathrm{T}}=\mathrm{Q}_{\mathrm{c}}+\mathrm{Q}_{\mathrm{w}}$, then

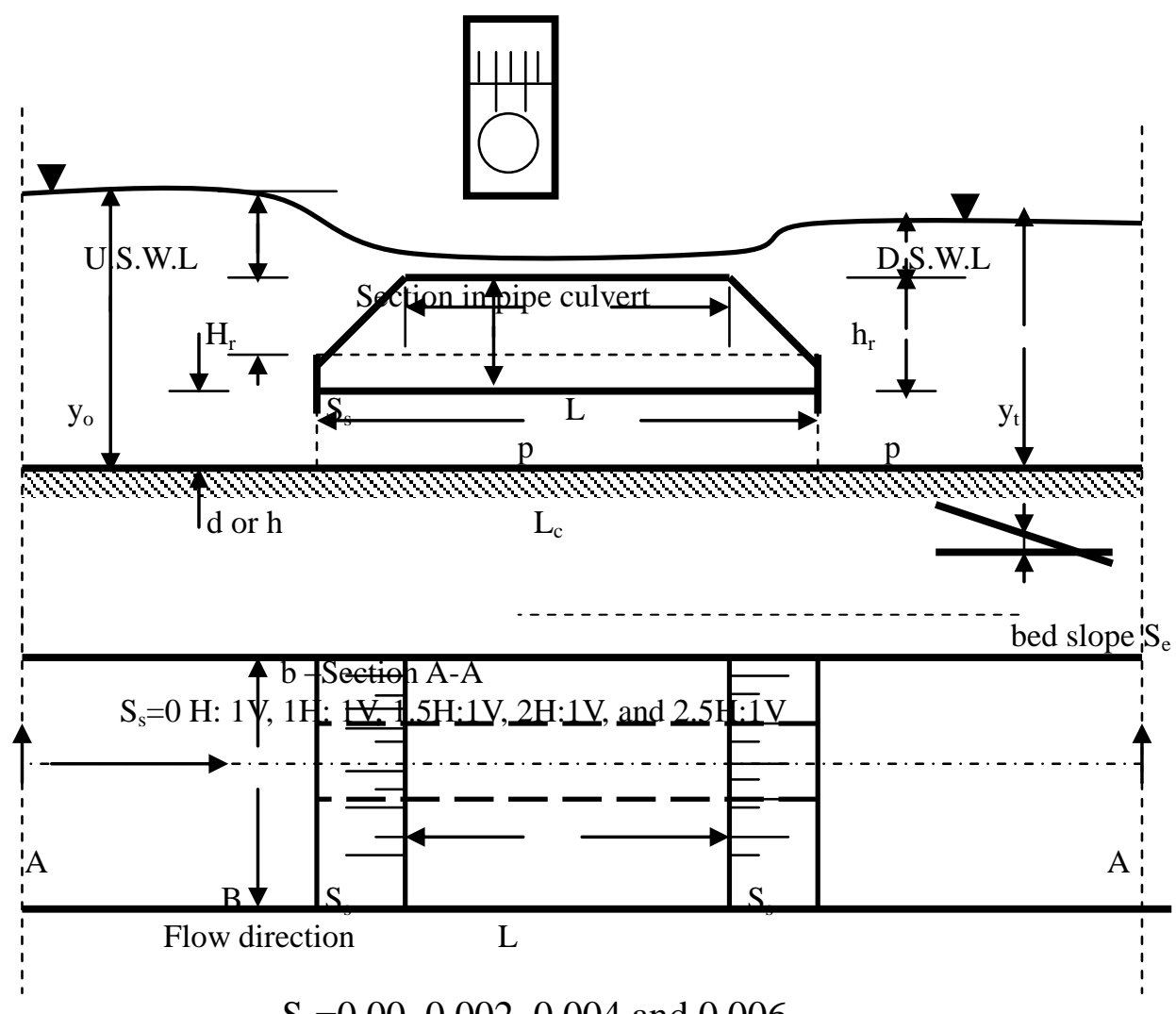

$\mathrm{S}_{\mathrm{e}}=0.00,0.002,0.004$ and 0.006

Plan of the tested model

Fig. (1): Schematic Diagram to Tested Models 
The parameters of the equations 1,2 , and 3 can be written in the following function: $\mathrm{f}\left(\rho, \mathrm{g}, \mu, \mathrm{Q}_{\mathrm{t}}, \mathrm{Q}_{\mathrm{c}}, \mathrm{Q}_{\mathrm{w}}, \mathrm{H}_{\mathrm{r}}, \mathrm{h}_{\mathrm{r}}, \mathrm{p}, \mathrm{B}, \mathrm{L}_{\mathrm{c}}, \mathrm{L}, \mathrm{y}_{\mathrm{o}}\right.$, $\left.\mathrm{y}_{\mathrm{t}}, \mathrm{S}_{\mathrm{s}}, \mathrm{S}_{\mathrm{e}}, \mathrm{C}_{\mathrm{dc}}, \mathrm{C}_{\mathrm{dw}}\right)=0.0$

By using the dimension analysis theory, the equation 4 can be formulated as follows: The discharge coefficient of highway crest can be written as follows:

$\therefore C_{d w}=f\left(\frac{Q_{w}}{Q_{T}}, \frac{Q_{c}}{Q_{T}}, \frac{H_{r}}{P}, \frac{h_{r}}{H_{r}}, \frac{H_{r}}{y_{o}-y_{t}}\right.$, $\left.\frac{H_{r}}{L}, \frac{y_{o}-y_{t}}{y_{o}}, S_{e}, S_{s}\right)$

\section{EXPERIMENTAL WORK}

Experiments were conducted to study the modification of highway above culvert to work as weir to remove the exceeded discharge. Experiments were conducted in a rectangular channel with a smooth bottom and two-glass wall $10 \mathrm{~cm}$ wide, $31 \mathrm{~cm}$ deep, and $300 \mathrm{~cm}$ long. The tailgate is fixed nearly at the end of the working section. It is an aluminum plate provided with a rubber cover at both sides to prevent leakage.

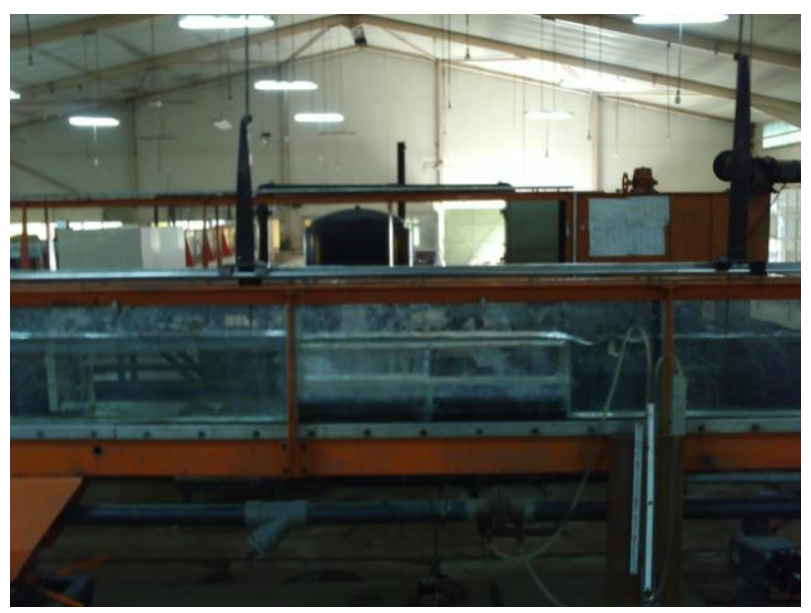

Photo (1): Vertical Angle Highway above Culvert

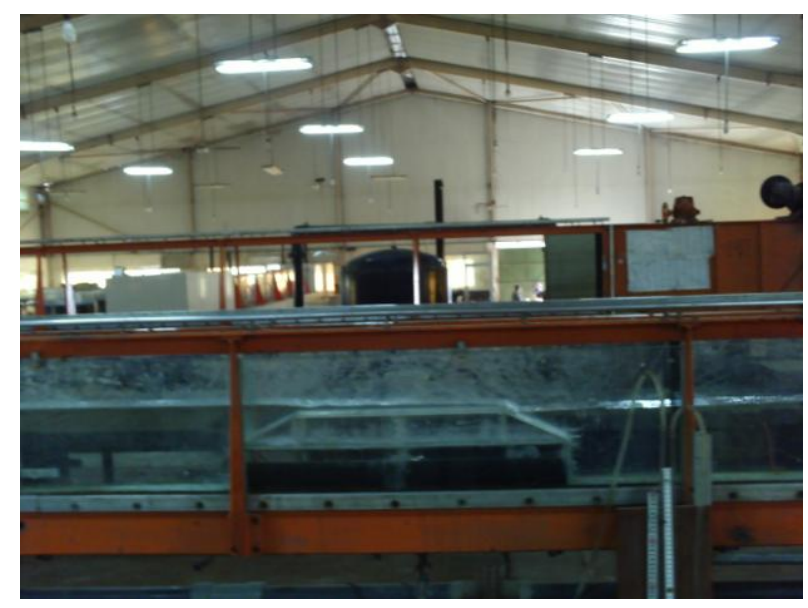

Photo (2): Upstream and DownstreamSloped Highway above Culvert

\section{DATA ANALYSIS}

\subsection{Discharge Coefficient of Culvert}


To determine the pipe culvert parameters to separate between culvert discharge and weir discharge, some of the experimental data are conducted in case of culvert only. From equation 1 , the $\mathrm{C}_{\mathrm{dc}}$ can be deduced as follows:

$$
C_{d c}=\frac{Q_{c}}{\sqrt{A_{o}^{2} \cdot 2 g \cdot\left(\left(y_{0}-y_{1}+S_{e} \cdot L_{c}\right)-\left(Q_{c}^{2} \cdot k \cdot n^{2} \cdot L_{c} / R^{4 / 3}\right)\right.}}
$$

In which: $\mathrm{A}_{0}=20.25 \mathrm{~cm}^{2}, \quad \mathrm{~L}_{\mathrm{c}}=75 \mathrm{~cm}$, $\mathrm{R}=1.27 \mathrm{~cm}$, and $\mathrm{S}_{\mathrm{e}}=0.00,0.002,0.004$, and 0.006., $\mathrm{k}=$ constant (29 for English system, and 19.65 for SI).

From data analysis, the $\mathrm{C}_{\mathrm{dc}}$ range is between 0.91 and 1.00 depening on channel bed slope. It can be determined from the empirical equation:

$$
C_{d c}=-2500 S_{e}-0.05 S_{e}+1.0015,
$$

for $\operatorname{Re}$ gression coeff. $R^{2}=0.9914$

\subsection{Effect of $\mathrm{Hr} / \mathrm{L}$ on Discharge Coefficient $\mathbf{C}_{\mathbf{d w}}$}

Figs. (2), (3), (4), and (5) show the correlation between the discharge coefficient $\mathrm{C}_{\mathrm{dw}}$ and the ratio of $\mathrm{H}_{\mathrm{r}} / \mathrm{L}$. The relationship is drawn with different bed channel slopes

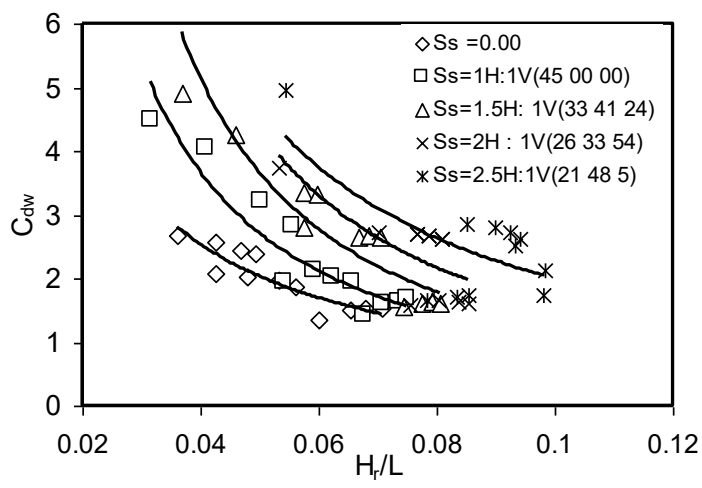

Fig. 2 Highway discharge coefficient $\mathrm{Cdw}$ versus $H_{r} / L$ at channel bed slope $S_{e}=0.00$, $0.02<\mathrm{H}_{\mathrm{r}} / \mathrm{P}<0.38$
$\mathrm{S}_{\mathrm{e}}=0.00,0.002,0.004$ and 0.006 . Also the highway upstream and downstream slopes are $0.00,1 \mathrm{H}: 1 \mathrm{~V}, 1.5 \mathrm{H}: 1 \mathrm{~V}, 2 \mathrm{H}: 1 \mathrm{~V}$, and $2.5 \mathrm{H}: 1 \mathrm{~V}$. The figure indicated that the discharge coefficient decreases as the ratio $\mathrm{H}_{\mathrm{r}} / \mathrm{L}$ increases. It also increases as the highway slope increases. The relations are represented for $0.02<\mathrm{H}_{\mathrm{r}} / \mathrm{P}<0.38$. To show the effect of the channel bed slope on the highway discharge coefficient, we take $\mathrm{H}_{\mathrm{r}} / \mathrm{L}=0.06$, and $\mathrm{S}_{\mathrm{s}}=0.00$, we fined $\mathrm{C}_{\mathrm{dw}}=1.75$ at $\mathrm{S}_{\mathrm{e}}=0.00,1.80$ at $\mathrm{Se}=0.002,1.95$ at $\mathrm{S}_{\mathrm{e}}=0.004,2$ at $\mathrm{S}_{\mathrm{e}}=0.006$. The amount of increase in $\mathrm{C}_{\mathrm{dw}}=12.50 \%$, when $\mathrm{Se}$ increases by $100 \%$. Also, the discharge coefficient increases by $16.6 \%$ at $\mathrm{Ss}=1 \mathrm{H}: 1 \mathrm{~V}, 30 \%$ at $\mathrm{Ss}=1.5 \mathrm{H}: 1 \mathrm{~V}, 41.7 \%$ at $\mathrm{Ss}=2 \mathrm{H}: 1 \mathrm{~V}, 128.5 \%$ when $\mathrm{Ss}=2.5 \mathrm{H}: 1 \mathrm{~V}$. This means that the effect of highway slope in upstream and downstream is more effective if compared with channel bed slope. Also, the amount of increase in upstream and downstream slope causes increases in removing discharge from flood of wadi.

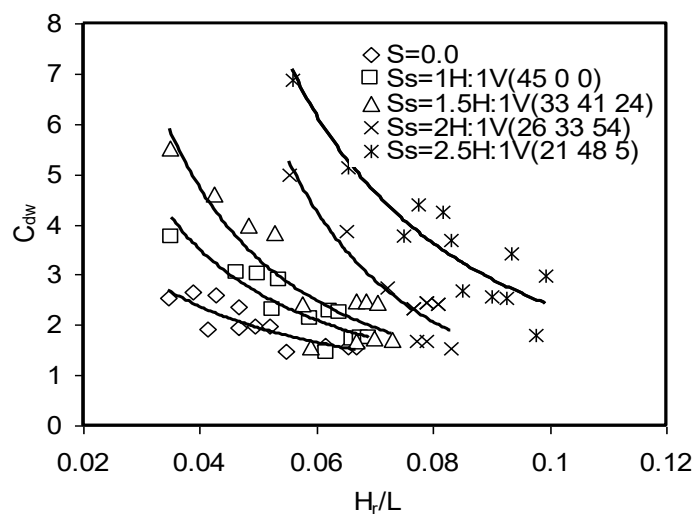

Fig. 3 Highway discharge coefficient $\mathrm{C}_{\mathrm{dw}}$ versus $\mathrm{H}_{\mathrm{r}} / \mathrm{L}$ for channel bed slope $\mathrm{S}_{\mathrm{e}}=0.002$, $0.02<\mathrm{H}_{\mathrm{r}} / \mathrm{P}<0.38$ 


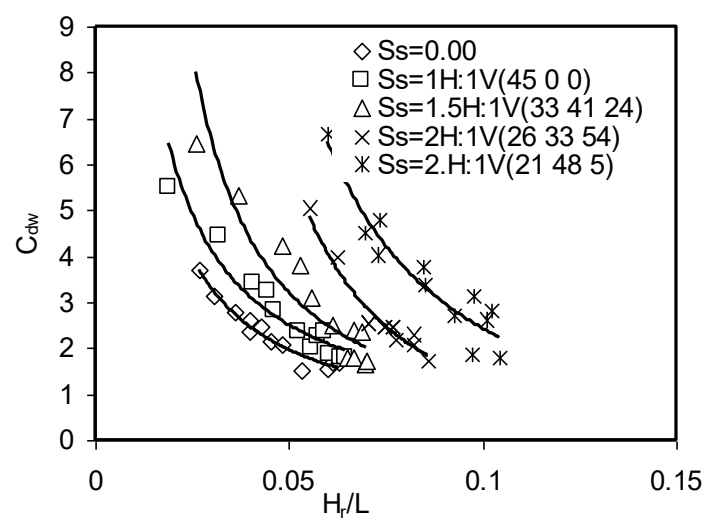

Fig. 4 Highway discharge coefficient $\mathrm{C}_{\mathrm{dw}}$ versus $H_{r} / L$ at chaneel bed slope $S_{e}=0.004$, $0.02<\mathrm{H}_{\mathrm{r}} / \mathrm{P}<0.38$

\subsection{Effect of $\mathrm{Hr} / \mathrm{P}$ on Discharge Coefficient $\left(\mathbf{C}_{\mathbf{d w}}\right)$}

From the previous studies, the heights of highway which work as broad crested weir affect on the flow characteristics. The ratio of $\mathrm{H}_{\mathrm{r}} / \mathrm{P}$ is ranged between 0.02 and 0.38 . Figs. (6), (7), (8), and (9) show the relationship between $\mathrm{C}_{\mathrm{dw}}$ and the ratio of $\mathrm{H}_{\mathrm{r}} / \mathrm{P}$. All figures indicated that the discharge coefficient decreases as the ratio $\mathrm{H}_{\mathrm{r}} / \mathrm{P}$ increases. The average percentage of $\mathrm{C}_{\mathrm{dw}}$

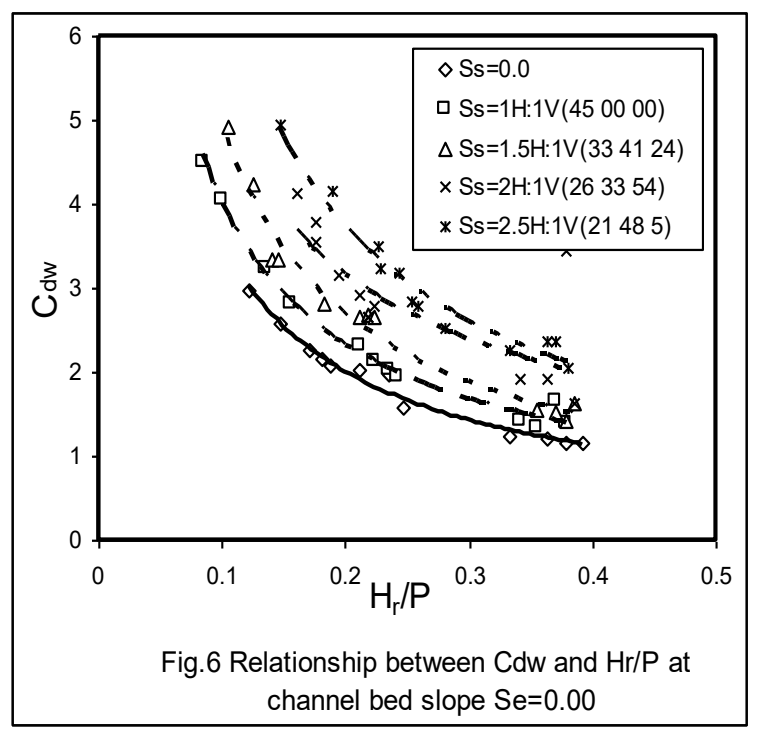

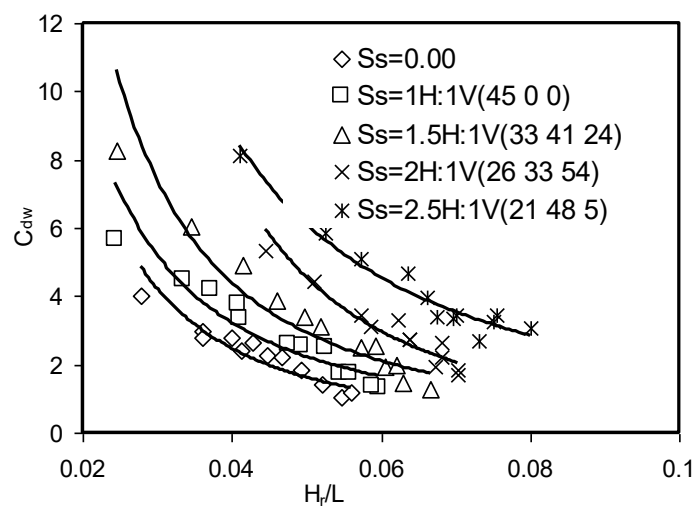

Fig. 5 Highway discharge coefficient $C_{d w}$ versus $H_{r} / L$ at bed channel slope $S_{e}=0.006,0.02<H_{r} / P<0.38$

decreases is $60 \%$ when $\mathrm{H}_{\mathrm{r}} / \mathrm{P}$ increases by $90 \%$. At $\mathrm{H}_{\mathrm{r}} / \mathrm{p}$ equals 0.2 , the increases in the discharge coefficient occurred relative to $\mathrm{S}_{\mathrm{s}}=0.0$ due to change in upstream and downstream highway slopes which are $28.57 \%$ at $\mathrm{S}_{\mathrm{s}}=1 \mathrm{H}: 1 \mathrm{~V}, 60 \%$ at $\mathrm{S}_{\mathrm{s}}=1.5 \mathrm{H}: 1 \mathrm{~V}$, $80 \%$ at $\mathrm{S}_{\mathrm{s}}=2 \mathrm{H}: 1 \mathrm{~V}, 105 \%$ at $\mathrm{S}_{\mathrm{s}}=2.5 \mathrm{H}: 1 \mathrm{~V}$. The amount of increase in the channel bed slope $\mathrm{S}_{\mathrm{e}}$ from 0.00 to 0.006 causes an amount of increase in the discharge $\mathrm{C}_{\mathrm{dw}}$ by $10 \%$.

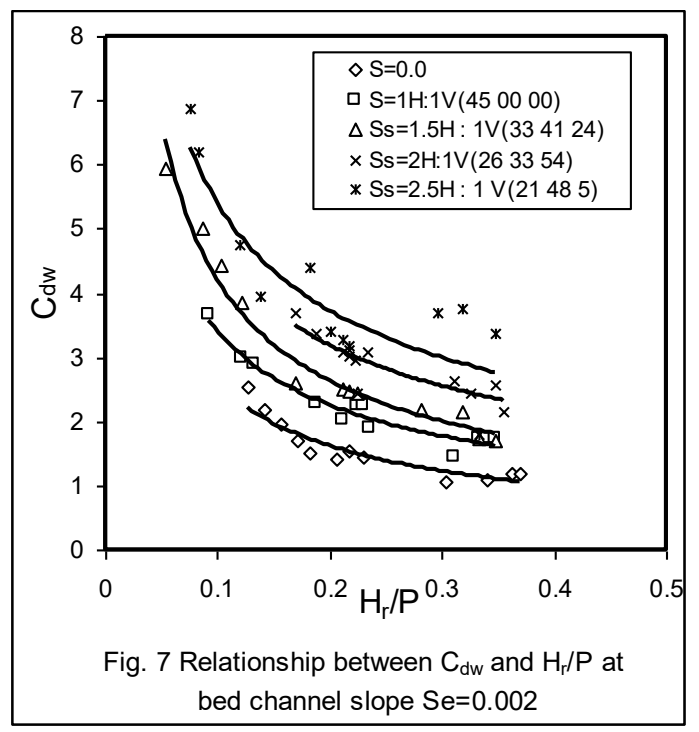




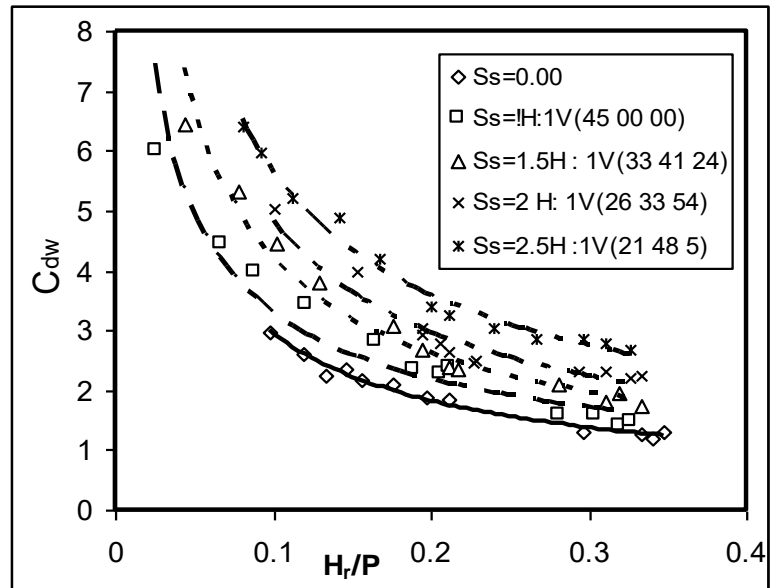

Fig. 8 Relationship between $\mathrm{C}_{\mathrm{dw}}$ and $\mathrm{H}_{\mathrm{r}} / \mathrm{P}$ at channel bed slope $\mathrm{Se}=0.004$

\subsection{Relationship between the Ratios of $\mathbf{Q}_{\mathrm{w}} / \mathbf{Q}_{\mathrm{T}}, \mathbf{y}_{\mathbf{0}}-\mathbf{y}_{\mathrm{t}} / \mathbf{y}_{\mathbf{0}}$ and $\mathbf{Q}_{\mathrm{c}} / \mathbf{Q}_{\mathrm{T}}$}

The relationship between $\mathrm{Q}_{\mathrm{c}} / \mathrm{Q}_{\mathrm{T}}$ versus $\mathrm{Q}_{\mathrm{W}} / \mathrm{Q}_{\mathrm{T}}$ is shown in fig. 10. The figure indicated that the ratio of $\mathrm{Q}_{\mathrm{C}} / \mathrm{Q}_{\mathrm{T}}$ increases of the ratio of $\mathrm{Q}_{\mathrm{w}} / \mathrm{Q}_{\mathrm{T}}$ decreases at all tested ratios of $\mathrm{H}_{\mathrm{r}} / \mathrm{p}, \mathrm{H}_{\mathrm{r}} / \mathrm{L}$, Se and Ss. The relation deduced from regression analysis is $\left(\mathrm{Q}_{\mathrm{W}} / \mathrm{Q}_{\mathrm{T}}\right)=0.9998-0.9997\left(\mathrm{Q}_{\mathrm{c}} / \mathrm{Q}_{\mathrm{T}}\right)$, at

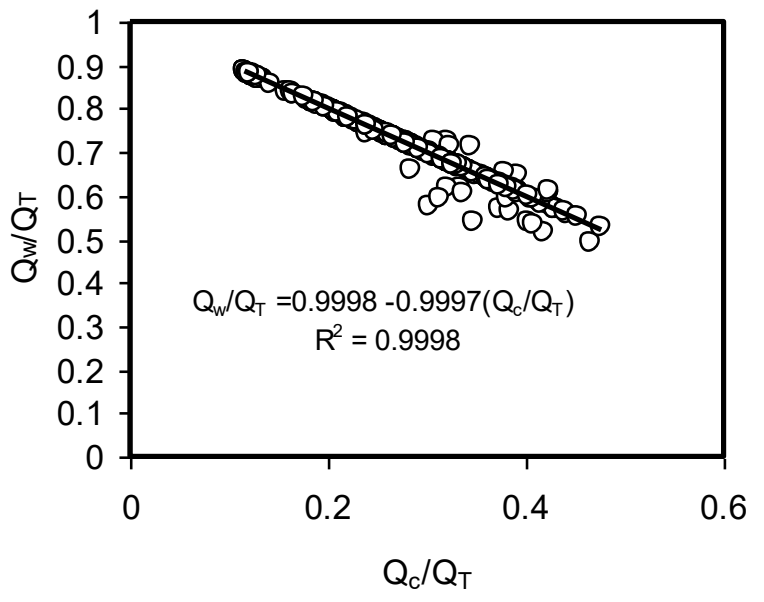

Fig. 10 Relationship between $Q_{c} / Q_{T}$ and $\mathrm{Q}_{\mathrm{W}} / \mathrm{Q}_{\mathrm{T}}, 0.02<\mathrm{h}_{\mathrm{r}} / \mathrm{P}<0.38,0.00<\mathrm{S}_{\mathrm{e}}<0.006$, $21^{\circ} 48^{\prime \prime} 5^{\prime}<\mathrm{S}_{\mathrm{s}}<90^{\circ}$

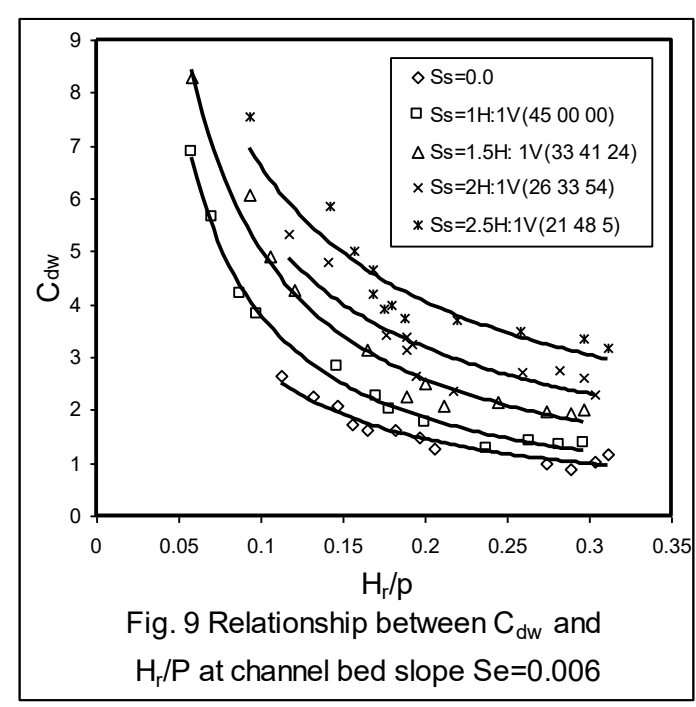

$\mathrm{R}^{\llcorner}=0.9998$. Fig. (11) shows the effect of the submergence factor on the culvert discharge. It shows that the submergence ratio $\mathrm{y}_{\mathrm{t}} / \mathrm{y}_{\mathrm{o}}$ increases as the ratio of $\mathrm{Q}_{\mathrm{C}} / \mathrm{Q}_{\mathrm{T}}$ decreases. This means that the rising in downstream water level causes a decrease in the efficiency of the culvert for increases in $\mathrm{y}_{\mathrm{t}} / \mathrm{y}_{\mathrm{o}}$ by $30 \%$, and the $\mathrm{Q}_{\mathrm{c}} / \mathrm{Q}_{\mathrm{T}}$ decreases by $47 \%$. The co-relation between $\mathrm{Q}_{\mathrm{c}} / \mathrm{Q}_{\mathrm{T}}$ and $\mathrm{y}_{\mathrm{t}} / \mathrm{y}_{\mathrm{o}}$ is $\mathrm{Q}_{\mathrm{c}} / \mathrm{Q}_{\mathrm{T}}=0.719-0.489\left(\mathrm{y}_{\mathrm{t}} / \mathrm{y}_{\mathrm{o}}\right)$ which is deduced by regression analysis.

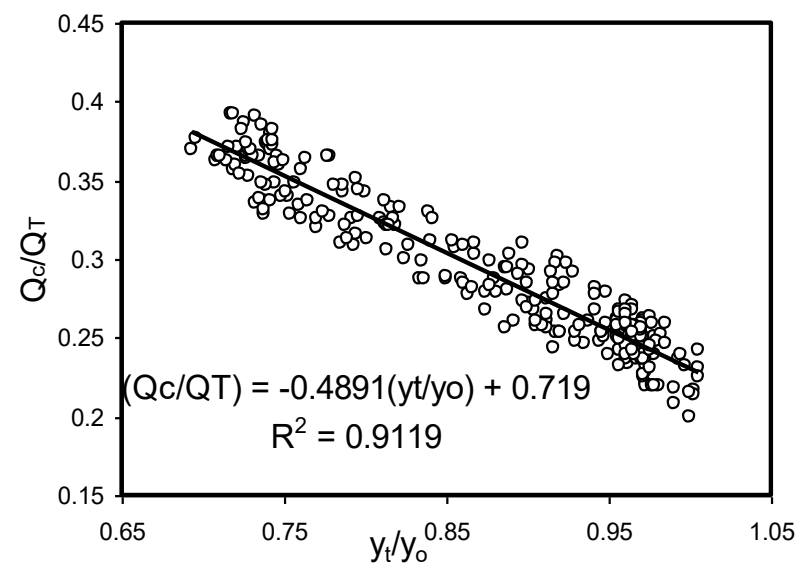

Fig. 11 Relationship between submerged ratio $\mathrm{y}_{\mathrm{t}} / \mathrm{y}_{\mathrm{O}}$ and $\mathrm{Q}_{\mathrm{C}} / \mathrm{Q}_{\mathrm{T}}, 0.02<\mathrm{hr} / \mathrm{P}<0.38$, $0.00<\mathrm{Se}<0.006,21048^{\prime \prime} 5^{\prime}<\mathrm{Ss}<90$ o 


\section{Developed Empirical Equations for $\mathbf{C}_{\mathrm{dw}}$}

Three empirical equations are developed to compute the discharge coefficient of highway above the culvert. Fig. (11) shows the co-relation between $\mathrm{C}_{\mathrm{dw}}$ versus $\mathrm{H}_{\mathrm{r}} / \mathrm{L}$ and the empirical equation can be written as follows:

$$
\begin{aligned}
& \mathrm{C}_{\mathrm{dw}}=0.0145^{*}\left(\mathrm{H}_{\mathrm{r}} / \mathrm{L}\right)-1.8591 \text { at } \\
& 0.00<\mathrm{S}_{\mathrm{e}}<0.006,21485<\mathrm{S}_{\mathrm{s}}<90, \mathrm{R}^{2}=90.78 \%
\end{aligned}
$$

The relationship between $\mathrm{C}_{\mathrm{dw}}$ and $\mathrm{H}_{\mathrm{r}} / \mathrm{P}$ is shown in Fig. (12) and can be written as follows:

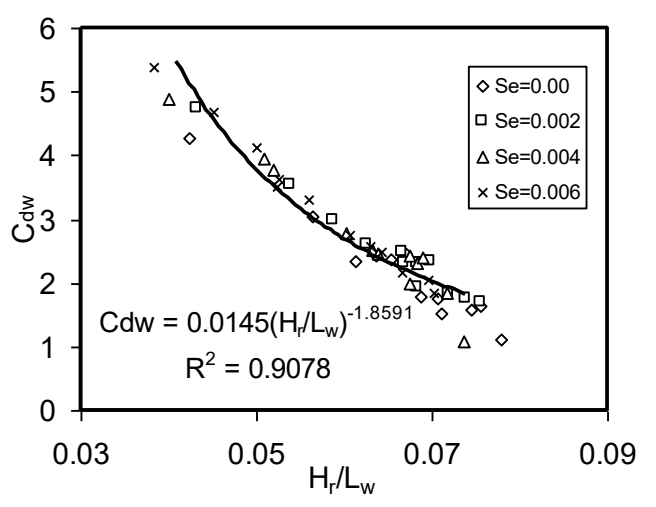

Fig. 12 Relationship between $\mathrm{C}_{d w}$ and $\mathrm{H}_{r} / \mathrm{L}_{w}$ at different bed channel slope $S_{e}$,

$\left(21^{\circ} 48^{\prime} 5^{\prime \prime}<\mathrm{Ss}<90^{\circ}\right)$
$\mathrm{C}_{\mathrm{dw}}=0.8021 *\left(\mathrm{H}_{\mathrm{r}} / \mathrm{p}\right)-0.7748$ at $0.00<\mathrm{S}_{\mathrm{e}}<0.006,21485<\mathrm{S}_{\mathrm{s}}<90, \mathrm{R}^{2}=98.24 \%$

and, the relationship between discharge coefficient $\mathrm{C}_{\mathrm{dw}}$ and upstream and downstream slopes Ss of the highway above culvert have been co-related due to regression analysis and can be written as follows:

$$
\begin{aligned}
& C_{d w}=10.657\left(\sin S_{s}\right) 2-18.48\left(\sin S_{s}\right)+9.6698 \\
& R^{2}=94.37 \%
\end{aligned}
$$
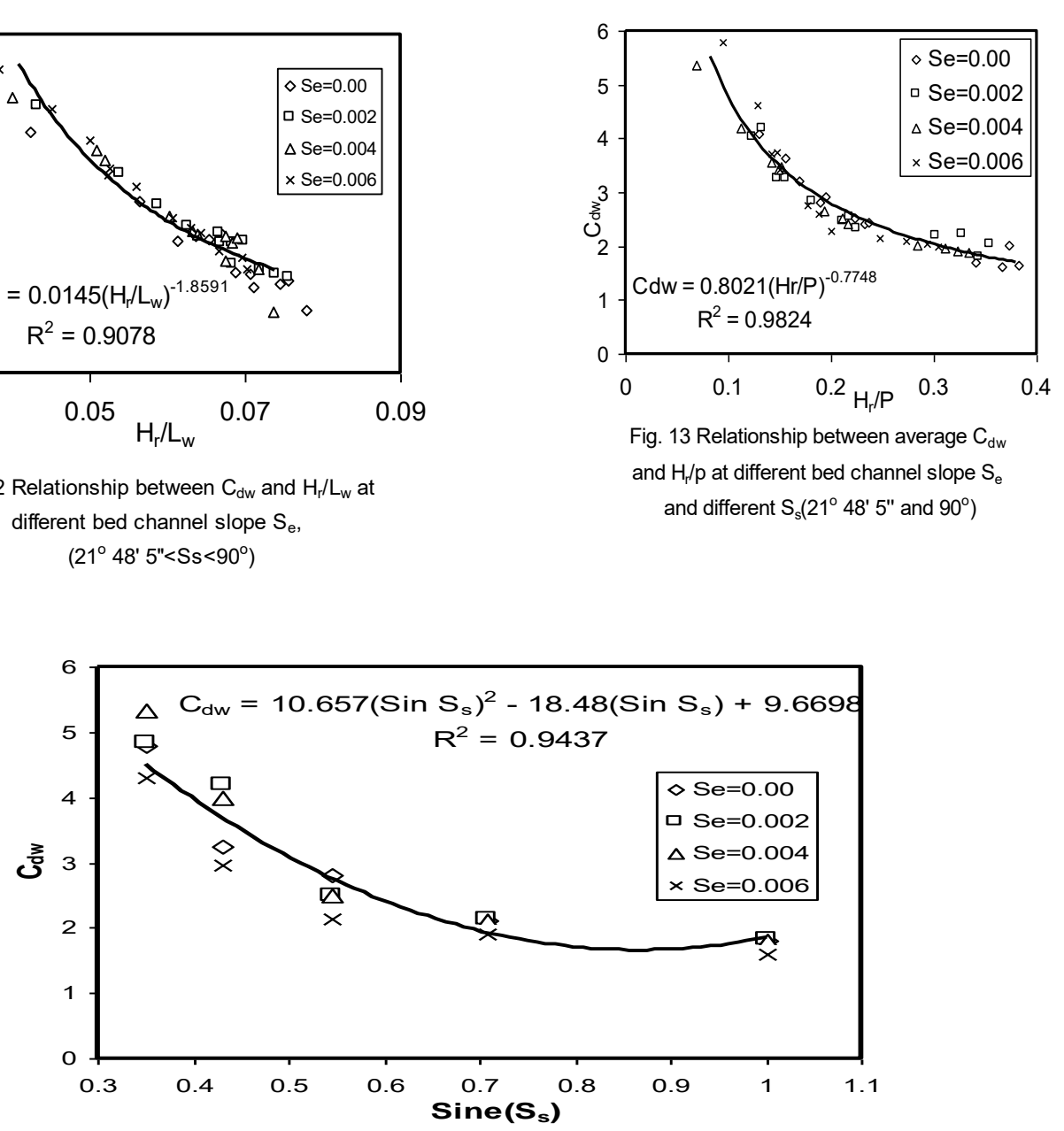

Fig. 14 Discharge cofficient $C_{d w}$ versus highway sloped $\mathrm{S}_{\mathrm{s}}$ at $0.03<\mathrm{H}_{\mathrm{r}} / \mathrm{L}<0.08$, $0.01<\mathrm{H}_{\mathrm{r}} / \mathrm{P}<0.40$ 


\section{CONCLUSIONS}

Extensive experimental work is conducted for submerged flow of culvert to study the hydraulic performance and characteristics of flow over highway above culvert to help in removing excess flow. The new shape of highway works as broad crested weir to be protected against failure. The main conclusion can be summarized as follows:

1. The increases in channel bed slope and weir side slopes resulted in increasing the discharge coefficients of culvert and broad crested weir above culvert.

2. For submerged flow, the discharge coefficients decrease as the ratio $\mathrm{H}_{\mathrm{r}} / \mathrm{L}$, and $\mathrm{H}_{\mathrm{r}} / \mathrm{P}$ increase.

3. Developing three empirical equations used to determine discharge coefficient of broad crested weir as a function of $\mathrm{Hr} / \mathrm{L}, \mathrm{Hr} / \mathrm{P}$ and upstream and downstream weir slopes.

4. The ratio of $\left(\mathrm{Q}_{\mathrm{c}} / \mathrm{Q}_{\mathrm{T}}\right)$ decreases as the submerged ratio (yo/yt) increases, and the ratio of $\left(\mathrm{Q}_{\mathrm{w}} / \mathrm{Q}_{\mathrm{T}}\right)$ increases for integrating weir with culvert to remove excess flow.

\section{REFRENCES}

1. Charbeneau, R. J., Henderson, A. D. and Sherman, L. C." Hydraulic performance curves for highway culverts." " J. of Hydr. Engrg, ASCE, Vol. 132 . No.5. Pp. 474-481, 2006.

2. Chow, V. T.(1959). "Open channel hydraulics". McGraw-Hill, Inc. New York.

3. Cordes, K. E. Hotchkiss R. H., "Design discharge of culverts" . NDOR research Project Number Res-
1(0099) P466, Transportation Research Studies, 1993.

4. Dasika, B., "New approach to design culvert". J. of Irrig. and Drain. Engrg. , ASCE, Vol.121, No. 3, Pp. 261-264, 1995.

5. French, R. H., "Open-channel hydraulics". McGraw-Hill, Inc. New York, 1985.

6. Fritz, H. M. and Hager, W. H., "Hydraulics of embankment weirs", J. of Hydr. Engrg, ASCE, Vol. 124. No.9. Pp. 963-971, 1998.

7. Hager, W. H. and Del Giudice, "Generalized culvert design diagram" J. of Irrig. and Drain. Engrg. , ASCE, Vol.124, No. 5, Pp. 271-274, 1998.

8. Kang, M. S. , Chun, J. A., Her, Y. G. and Yoo, K., "Design of drainage culverts considering critical storm", Biosystems Engineering vol. 4, 425434, 2009.

9. Keler, R. J., "Sloping crest crump weir", J. of Irrig. \& Drain. Engrg., ASCE, Vol.115, No. 2, Pp. 231-238, 1989.

10. Masada, T., Sargand, S. M. , Tarawneh, B. , Mitchell, G. F. and Gruver, D., " Inspection and risk assessment of concrete culvert under Ohio's highways". Journal of Performance of Constructed Facilities, ASCE., Vol. 21, No. 3, Pp.225-233, 2007..

11. Meselhe, E. A. and Hebert, K., "Laboratory measurements of flow through culvert", J. of Hydr. Engrg, 
ASCE, Vol. 133. No.8. Pp. 973-976, 2007.

12. Mohamed H. I., "Flow over gabion weirs". J. of Irrig. and Drain. Engrg. , ASCE, Vol.136, No. 8, pp. 573-577, 2010.

13. Najafi, M. and Bhattacher, D. V., "Development of a culvert inventory and inspection framework for asset management of road structures". J. of King Saud University (Science), September, 2010.

14. Sargison, J. E. and Percy, A., "Hydraulic of broad-crested weirs varying sid slopes". J. of Irrig. and Drain. Engrg. , ASCE, Vol.135, No. 1, Pp. 115-118, 2009.

15. Sarker, M. A. and Rhodes, D. G., "Calculation of free-surface profile over a rectangular broad-crested weir", Flow Measurement and Instruments Vol.15, Pp. 215-219, 2004.

16. Scholl, B. N., Thornton C. I. and Barrie King, E.I.T., "Overtopping flow protection", CONTECH Construction Products Inc., 2009.

17. Texas Department of Transportation, "Hydraulic Design Manual". Taxes Department of Transportation (512) 416-2055, 2004.

18. U.S. Department of Transportation, "Hydraulic design of Highway Culverts". Publication N0. FHWANHI-01-020, 2001.

19. U.S. Department of Transportation, "Hydraulic design of energy dissipaters for culverts and channels, hydraulic engineering circular No. 14, third edition". Publication N0. FHWA-NHI-06-086, 2006.

20. Wols, B. , Uijttewaal, W. Labeur, R.J, and Stelling, G., "Rapidly varying flow over oblique weirs". The seventh international conference on hydro-science and engineering, USA, September, 2006. 